HOW Journal

Volume 27, Number 1, pages 125-139

https://doi.org/10.19183/how.27.1.520

\title{
县OW
}

\section{A Self-Dialogue with the Thoughts of Paulo Freire: A Critical Pedagogy Encounter}

\author{
Un diálogo personal con los pensamientos de Paulo Freire: \\ un encuentro de pedagogía crítica
}

\section{Samacá Bohórquez, Yolanda ${ }^{1}$}

\begin{abstract}
This paper develops a two-voiced self-dialogue with some compelling ideals of critical pedagogy advocated by Paulo Freire: reflection, dialogue, conscientização, (conscientization) praxis, critical engagement, and transformation. This dialogue, as a critical pedagogy encounter, has allowed me to go through a process of self-criticism or hopefully a self-recognition of understandings, experiences, constructions, co-constructions, and reconstructions of my practices as a language educator. I will address the following evolving choices: On dialogue and critical pedagogy, from language as power to language as possibility, from instrumental to alternative critical pedagogy practices towards more critical understandings and doings of education.
\end{abstract}

Keywords: conscientização, critical engagement, praxis, self-dialogue, reflection.

\section{Resumen}

Este documento desarrolla un diálogo personal a dos voces con algunos ideales de la pedagogía crítica defendidos por Paulo Freire: reflexión, diálogo, concienciación, praxis, compromiso crítico y transformación. Este diálogo, como encuentro pedagógico crítico, me ha permitido atravesar un proceso de autocrítica o, con suerte, un autorreconocimiento de comprensiones, experiencias, construcciones,

\footnotetext{
Yolanda Samacá Bohórquez is a teacher educator at Universidad Distrital Francisco José de Caldas, Bogotá, Colombia. She holds a BEd (Spanish-English) from Universidad Pedagógica y Tecnológica de Colombia, UPTC, Tunja, a graduate degree in Pedagogy of Written Processes from Universidad Santo Tomás, Bogotá, and an MA in Applied Linguistics to the Teaching of English as a Foreign Language from Universidad Distrital Francisco José de Caldas. At present, she is a Doctorate student in the ELT Emphasis at the Interinstitutional Ph.D. Education Program from the same university. ysamacab@udistrital.edu.co http://orcid.org/0000-0003-0072-073X
}

Received: May 28th, 2019. Accepted: October 29th, 2019

This article is licensed under a Creative Commons Attribution-Non-Commercial-No-Derivatives 4.0 International License. License Deed can be consulted at https://creativecommons.org/licenses/by-ncnd/4.0/ 
co-construcciones y reconstrucciones de mis prácticas como educadora de idiomas. Abordaré las siguientes opciones en evolución: sobre el diálogo y la pedagogía crítica, del lenguaje como poder al lenguaje como posibilidad, de las prácticas instrumentales a las alternativas de la pedagogía crítica hacia las comprensiones y las actividades educativas más importantes.

Palabras clave: concienciación, compromiso crítico, praxis, diálogo personal, reflexión.

\section{Introduction}

Reflection, dialogue, conscientização, praxis, critical engagement, and transformation are compelling ideals that critical pedagogy (henceforth $\mathrm{CP}$ ) advocates. CP seeks praxis, constituted in "action and reflection" (Freire, 1985). CP involves "thinking about what and why you're going to do before you do it and then reflecting on what you did, how you did it, and how it turned out" (Monchinski, 2008, p. 1). Freire's passion for social justice is a principle underlying critical pedagogy. This principle is revealed when teaching and learning become human experiences; when personal, social, political, and cultural dimensions also take a place in educational contexts, and when all these are extended to communities to unveil their oppressions. Thus, in Freire's social pedagogy: “education is one place where the individual and society are constructed, a social action which can either empower or domesticate students" (Shor, 1993, p. 25).

$\mathrm{CP}$ as a form of life entails a never-ending constant dialogical relationship with ourselves, our students, and our colleagues within our educational, social, and political contexts, everything with the purpose to inform and situate our practices. All this is insightful but challenging, because no matter how difficult the panorama sometimes looks in education with this neoliberal system ${ }^{2}$, which domesticates, homogenizes, and objectifies people, I always find someone, something, or somewhere that inspires me to do things differently and to become more sensitive and critical of what I do, or intend to do, as a language teacher educator.

This is my experience when having critical encounters ${ }^{3}$ with friends, students, colleagues, professors, and sources of inspiration, who have taken seriously the idea of understanding, interpreting, and challenging our educational practices, or trying new ways of doing things

Neoliberalism in higher education, for example, undergoes tremendous control from the government in the accreditation processes in Colombia, using a subtle discourse to provide freedom but at the same time reducing that academic freedom when teacher researchers' work needs to suit the demands of the educational policies for a 'globalized' world.

I have used the word 'critical' because these encounters have provoked changes in perspectives, actions, and ways to envision education. For Pennycook (2001), critical is "doing something with careful analysis" and being critical as "being engaged with social change" (p. 11). Freire (2005) thought of dialogue as "the encounter between men, mediated by the world, in order to name the world" (p. 88). In Samacá (2012), critical is interpreted as a permanent inquiry about what teachers have been, what they are, and what they will become in the future as teachers as well as how pre-service teacher education might support them in this goal. 
on a daily basis. Then, this paper expresses a two-voiced self-dialogue as a process of selfcriticism or hopefully a self-recognition of understandings, experiences, constructions, coconstructions, and reconstructions of my practices as a language educator, supported by the critical pedagogy thought of dialogue and conscientização in Paulo Freire. I will discuss the following evolving choices: dialogue and critical pedagogy, from language as power to language as possibility, from instrumental to alternative CP practices towards more critical understandings and doings of education.

\section{On Dialogue and Critical Pedagogy}

"Dialogue is thus an existential necessity. And since dialogue is the encounter in which the united reflection and action of the dialoguers are addressed to the world which is to be transformed and bumanized, this dialogue cannot be reduced to the act of one person's "depositing" ideas in another, nor can it become a simple exchange of ideas to be "consumed" by the discussants." (Freire, 2005, pp. 88-89)

Freire (2005) claims that dialogue is a human phenomenon; the word is the essence of dialogue. This word has two dimensions: reflection and action. For him, "There is no true word that is not at the same time praxis. Thus, to speak a true word is to transform the world." (p. 87). This entails that action and reflection take people to action (praxis); however, reflection without action is verbalism. From this Freirean perspective, the dialogue is the encounter between humans (Freire, 2005); it is through dialogue that we, people, can reflect and make decisions about how to transform our own communities through the communicative and pedagogical encounters that we, English language teachers, have with our students and colleagues. Education in this perspective opens the possibility to rethink, critically situate our educational contexts, classrooms, as well as practices, and take risks in our own teaching and learning. In the dialogue that I intend to develop here, I talk with myself, a dialogue between "I and me," where the word is used to illustrate how critical pedagogy has nurtured the forms of seeing education from a more sensitive and local perspective in my life as a language educator.

Shaw (2001) asserts that self-dialogue is a fundamental process of expression, a conversation among different identity perspectives within oneself “containing one's idealized state of affairs, perceived image of reality, and intended scheme of action, as well as intercommunications between and among those mental domains of mind" (p. 279). These are valuable ideas that take me to look at self-dialogue as a conscious expression when I think about myself, my desires, my dreams, my struggles, my existence, my relationships with others; when I expect to portray some hegemonic forces ${ }^{4}$ that exist in our profession and that are not easy to recognize because they have been naturalized. This is what Freire names conscientização, a process of self-

\footnotetext{
These hegemonic forces relate to the dynamics of oppression that Shor \& Freire (1987) identify, and how these dynamics are present in teaching and learning processes that are extended to "many forms of social oppressions that play out in the lives of students" (Kumashiro, 2000, p. 25).
} 
affirmation and recognition of social, cultural, political, and economical contradictions that influence the forms in which education has been conceived at all levels.

In this regard, Freire (2005) states that educators should reject the banking model of education, in which teachers are the ones who possess knowledge and deposit it in students. We, educators, cannot impose our own view of the world on people, nor can we assume dialogue as a simple "exchange of ideas to be "consumed"' (p. 89), but rather we can share together the views of our world through a dialogue that represents a dialogical, practical, and reflexive action upon our immediate worlds.

In an earlier study, Samacá \& Bonilla (forthcoming) have argued that to assume a perspective and act critically in education, thinking of dialogue as a horizontal relationship is necessary to share ideas and experiences that enable teachers' construction and pedagogical knowledges that underlie the nature of being and becoming a teacher. This entails a dialogue that acknowledges the other, that documents how we, teachers, assume the teaching and learning processes in our educational contexts. This understanding of dialogue might also endorse teachers' voices, address problems from different perspectives, re-signify what happens in our contexts and promote new forms of work, interaction or positioning, and a dialogue that informs our decisions.

These tenets of $\mathrm{CP}$ acknowledge multiple understandings of relating to education and pedagogy. Therefore, a dialectical perspective recognizes the existence of power relationships that can find a place for people to speak and to be heard through dialogue and dialectical interactions. In this relationship, everyone has diverse ways of understanding their realities, because no one knows everything, no one ignores everything. From a more political and pedagogical perspective, Giroux (2007) has declared that "It is impossible to separate what we do in the classroom from the economic and political conditions that shape our work, and that means that pedagogy has to be understood as a form of academic labor in which questions of time, autonomy, freedom, and power become as central to the classroom as what is taught" (p. 3).

This idea engages teachers and learners in thinking about what happens outside our classrooms and institutions, or if we think about those happenings, what views are we assuming? Do we intend to understand ourselves as political? If so, what decisions do we make in relation to that political dimension in our curriculums, in our research studies? How do we create relationships with the real world out there? How do we see ourselves in our communities? Giroux (2007) clearly affirms that pedagogy cannot be "a merely methodological consideration... but, the cornerstone of democracy is that which provides the very foundation for students to learn not merely how to be governed, but also how to be capable of governing" (p. 3). Thus, empower students and teachers to intervene in our own self-formation processes and care about our cultural, social, and political history. 
$C P$ has influenced my experience in language teaching and learning; it has given more situated meaning to make sense of who I am as a language educator, and what my profession embraces. I have evolved from a very interesting pedagogical formation both in my school formation as a Normalistas and in my B. Ed. Program, to a more critical stage of what I do; from my experience in the Master's Program, through the critical dialogues, encounters, and research projects in which I have been involved. CP has definitely influenced the ways in which I understand teaching and learning, because CP is not a theory, but rather a way of 'being' a language educator, a way of 'doing' learning and teaching, and a way of 'knowing' through this pedagogical process, a philosophy of life, or as I have named it, a 'reevaluation of what we teachers are doing in our classrooms, expanding it to continually redefining myself and the contexts ${ }^{6}$ in which I am involved in. This entails a personal analysis of who I am and am becoming, because the ways I think about education today are totally different from what I used to think and do as a language teacher. I think that it is about an academic growth that is shaped, challenged, and transformed through my years of experience, something that I cannot save my student teachers, for example. They will walk, and live their paths and will continuously deconstruct the meanings of teaching through their experiences.

I am becoming even more sensitive to the realities of my country, where all that matters seems to be power to undermine others, where transformations driven by a neoliberal framework have potentially generated a discourse of growth that people usually believe in, and which has taken us to compete, produce, and follow standardized processes, as if everyone needed to do the same, even worse, be the same. I am becoming more responsive to the challenges we face and struggle in education and becoming more conscious of different oppressive and pervasive ways of the system. It has been through readings, critical dialogues in our courses, research groups, and conferences that we understand the subtle- hidden agenda: empty vessels filled with basic information to do a job, without thinking, that in the field of language teaching, all this is even simpler, but at the same time pervasive: learning English, certifying it and teaching it, being a language instructor, and having a good salary, not from experience, studies, but from an English level; all this by ignoring the particularities and specificities of situated contexts and communities.

For those who think that reflections about critical pedagogy need to go beyond the ideals, it is true; but these understandings and practical realizations of CP are becoming more visible in the language teaching profession. Nonetheless, another idea comes to mind... How can language teachers move beyond when people do not even realize that they have been oppressed?

By the same token, McLaren (2003) defines CP as "a way of thinking about, negotiating, and transforming the relationship among classroom teaching, the production of knowledge, the institutional structures of the school, and the social and material relations of the wider community, society, and nation-state" (p. 345). Paulo Freire's CP seeks to "make oppression

Normalista is the title I received at school, because I was prepared to teach in elementary school. This program in Colombia is known as "Escuelas Normales".

Contexts are schools, classrooms, teacher education programs, and communities in and from which teachers are naming themselves and so, they should not be passive anymore. 
and its causes objects of reflection by the oppressed" with the hope that "from that reflection will come liberation" (2005, p. 46). CP is inspiring when, day by day, no matter if issues of hurt, despair, nonconformity, or indifference take place in our educational contexts we, parents, teachers, and students, assume a more determined attitude and ways of doing things to challenge and transform them, simple actions that can change a life.

$\mathrm{CP}$ then as a philosophy of life entices teachers into a more sensitive, more contextualized, and more engaged discussion in order to understand what second language pedagogy encompasses and to unmask the oppressive agendas affecting our beliefs and practices. From the perspective of CP, I see myself as an educator, a learner, and a facilitator in the teaching and learning process, as both are relevant, both have implications for teachers and students, and their contexts...

\section{From Language as Power to Language as Possibility}

"Who says that this accent or this way of thinking is the cultivated one? If there is one that is cultivated, it is because there is another which is not, it is impossible to think about language, without thinking of ideology and power. I defend the duty of the teachers to teach the cultivated pattern and I defend the rights of the kids or of the adults to learn the dominant pattern... it is necessary to explain, to make clear to the kids or the adults, that their way of speaking is as beautiful as our way of speaking. "Freire (1996)

A first point I want to address is the power of English in our contexts. I would affirm, in connection to the insights by Tollefson (2000, as cited in Pennycook, 2007), that English has represented social and economic development for nations. By the time I started to learn English at the university, I was astonished about what this language represented: the possibility to speak the language, to know about other cultures, other people, to travel to English speaking countries mainly, to sound native-like, because speaking the way they do would give me a higher status and a higher salary. I felt fascinated about my career. My English language teachers, with quite different ideologies, I remember, encouraged us to learn and use the language. Everything that was asserted in regard to learning English was accepted. We thought it was normal that by that time people had to learn English and communications technology, and our peers choosing French were not making a good decision...

English represented, and still does, power, opportunity, and development. It has been conceived as the most important language to learn here in Colombia and in other Latin American countries, because of the neoliberal practices that have ruled education ${ }^{8}$. Everyone might see this on the mass media or when walking on the streets; English is the passport to

\footnotetext{
An incredible conversation'. Interview with Paulo Freire at the World Conference on Literacy organized by the International Literacy Institute(ILI) in Philadelphia, USA. An interview available at the http://www. freire.org/paulo-freire

8 In this regard, Giroux (2007) argues that "memory is erased and the political relevance of education is dismissed in the language of measurement and quantification." (p. 3)
} 
success, the key to advancement in our professional lives, to have better jobs, better salaries in an endless desire to be competent.

This fact has embraced, from the perspective of Phillipson (2003), the idea that "the use of one language generally implies the exclusion of others" (p. 17); a homogenizing position that has definitely oppressed ${ }^{9}$ other languages and communities on behalf of the spread of English, positions that people in general would defend when they have not considered the power behind what this language represents. It is an increasing monolingualism in English speaking countries, and a conflicting understanding of bilingualism in English speaking peripheral countries ${ }^{10}$. Thus, I might affirm that English and English language teaching seem to be normalized in this contemporary world. It is important to learn English, but other languages too, to have the real and equal opportunity to interact in a multidimensional world through different languages to achieve "significance as human beings" (Freire, 2005, p. 86). It is insightful and may be contradictory for me to find myself in a dialogue that allows me to dig into the implications of using a language that might deny others, as Freire pointed out, "whose right to speak their world has been denied to them" (p. 86) because they do not speak the language of domination.

...They need to learn the so-called dominant syntax for different reasons; that $I$, the more the oppressed, the poor people, grasp the dominant syntax, the more they can articulate their voices and their speech in the struggle against injustice." (Freire, 1996) ${ }^{11}$ )

A second point, derived from what has been mentioned above, is the native-like model that is implicitly assumed when teaching and learning English. It seems to be a matter of high achievement, demonstrating the so-called proficiency. I have felt that, in some stages in our lives, it was necessary to avoid our Colombian accent when speaking to people in English; we might have felt nervous and anxious when talking to native speakers of this language. What does it mean to give up an accent or to suppress it?" (Lippi-Green, 1997, p. 63) It might mean that the ideology ${ }^{12}$ of everything that comes from that "native-ideal" is better, but natives from the inner circle (the USA, England, Canada, Australia, and New Zealand), that ideology of not giving our languages(s) the place it (they) deserve(s) needs to be contested and redefined, because sometimes in our society, some people think and feel that our language(s) is/are less significant, exclude us from the social world, and that the discourse of growth leads us to standardization processes. We, educators, are all invited to

Recognizing oppression as harmful dispositions is relevant to denounce, contest and little by little redefine the role English plays in our communities.

10 Term used by Phillipson (2003) to illustrate countries that follow the linguistic norms of the core English speaking countries (p. 17).

11 Freire, P. (1996). 'An incredible conversation'. Interview with Paulo Freire at the World Conference on Literacy organized by the International Literacy Institute in Philadelphia, USA. Available at: http://www. freire.org/paulo-freire

12 Forms of understanding the world that shapes our actions. 
demonstrate that English cannot be assumed for certification only ${ }^{13}$ and that by no means teaching and learning processes can be reduced to this valid but limited way.

Time passed and, as a professional, I found there was a desire to travel. People told me that I had to travel, because I was going to learn the language in a real context. However, I did not see that as my main purpose, but to learn more about the North American culture and its people. This became a significant experience, because I could gain evidence that I had been able to learn English in my own country. What I did in the USA and Canada was to have an intercultural experience; however, contradictions were present... I ended up enrolled in an English course there, receiving a certificate that would give me more chances to find a better job when I came back. It happened. I remember that a first question in my first job interview was about my experience in an English speaking country. I felt fascinated because I met schools' expectations. I must say that when these memories come alive today, I know what it feels like when being absorbed by the system. Why did I feel fascinated because of this? I needed a job, as someone else did, and it gave me comfort, apparent stability, and commodities. Something the neoliberal system today proclaims with technical programs and English language certifications, making people feel that it is what they need... I worked for private schools where English had a tremendous impact on the curriculum and class materials. I worked with a wonderful native English-speaking teacher who knew about education; the teachers belonging to the English department were all working together, even my boss. He had taken seriously the implications of teaching and learning English from a socio-cultural perspective. However, it was not fair when I noticed that native Englishspeaking teachers, with no idea about pedagogy, earned higher salaries. Once again, the native English speaker would get a higher status at these private schools. What is even more dramatic is that in an indirect form local people also acknowledge that status... I claim this is not fair, because English language teachers in Colombia have prepared professionally to be English language teachers, ever better, to be 'educators', we are conscious of the responsibility we have in our hands, guiding students in their life projects, dealing with students' personal, academic, and life situations, in which the language that we speak is the language of possibility, communication, understanding... I claim that this is not fair, because the higher status that people may most of the times give the native English-speaking teachers, who are not possibly a professional in education, is denied to us. I do not mean to assume a position against them, but to our pervasive system and beliefs that seem to measure and hierarchize everything, denying again the richness of what we are.

The demand for learning English and having native-like models to teach or learn it are salient aspects manifested on a daily basis because of the socio-economic and political demands of neoliberalism ${ }^{14}$. This is what Lippi-Green (1997) calls the standard language ideology, defined as a "bias toward an abstracted, idealized, homogeneous spoken language which is imposed and maintained by dominant bloc institutions and which names as its model the written language" (p. 64), and which, in my point of view, intends to deny other Englishes

This is what Magrini (2014) describes as technical, instrumental approaches that aim at the production of knowledge.

14 A neoliberalism that has focused on three fundamental aspects: Political economy of educational financing; links between education and work, and standards of academic excellence (Mayo, 2015). 
in a world where there are more non-native English speakers than native ones. In a pluralistic world, we should have the right to speak the way we do; that, for sure, represents where we are proudly coming from. What I have learned through all these years is to acknowledge people's contributions and ideas rather than their accent.

In my experience throughout those initial years, and at the time of starting to work at the university level, the pressure was harder and harder. On the one hand, I was supposed to teach English at the very beginning of classes; on the other, I was working with those who once were my teachers. What a challenging experience it was...

\section{From Instrumental to Alternative CP Practices}

"A critical understanding of education, thinking about experience... the more I think about what I did and what I proposed, the more I understand myself." (Freire, 1996)

Freire is one of those inspiring sources who have given meaning to what $\mathrm{CP}$ represents: self-reflection, critical engagement, identifying and denouncing forms of oppression, and looking for ways of social transformation that should start being forged in our educational institutions. His ideas represent a challenge mainly when the technical perspectives are the ones that the system always favors; just to name a few of them: following the standard teaching methods and textbooks that have intended to homogenize ELT classroom practices, learnings, and interactions; use of the language to have a near native-like control; and believing in language certification as the only form to demonstrate language proficiency. These ideas have definitely maintained a pedagogical knowledge that is expanded by Western thinking, showing, apparently, that there are limited ways to teach and learn a language. The challenge is to start by recognizing that there are forms of oppression, but through experiences and encounters with inspiring sources in the field that nurture education, we can grow as persons, teachers, learners, and citizens, and through the understanding that education and our profession are based on the principles of acknowledging others, lessening the inequalities present in our educational systems, and being responsive to pluricultural, plurilingual, antiracist, inclusive agendas in our local contexts, reflected in our actions.

At the same time, I was enrolled in a Master's Program that transformed my perspective towards English and ELT; it was thought-provoking and invited me to recognize those dominant ideologies that have not allowed us to be who we really are. It was a seminar on CP that provoked reactions and attitudes that have taken me to rethink, relearn, and redefine not only myself as a Spanish-English speaker but also as a language teacher educator, then, in an initial language teacher education program. These encounters with preservice teachers were really significant for getting to know more about them and why they had made the decision to become teachers. A few of them, I remember, had thought of becoming teachers; however, some others at the very beginning were enrolled in the program because of English, but ended up loving this profession and confronting the social and cultural contexts they came from and would like to go back, to, assuming and taking with them that critical understanding of education. That was revealed in the research study I conducted in 
the MA program, a study in which I also confronted the ways to think about ELT, positioning myself as an educator, more than as an instructor.

Teaching a language from an instrumental perspective entails methods, memorization, test-taking, and normalized classroom practices given by 'experts' around the world, as if teachers and learners were the same and had the same economic, social, cultural and political contexts everywhere. This means that we have not been given the chance to think about other forms of learning and teaching English, because the didactic framework that indoctrinates teachers and students has already been conceived in our area and these are the discourses we have been exposed to. Once again, these subtle ways of oppression are present to tell us that our purpose is to be conforming and passive technicians (Crandall, 2000; Kumaravadivelu, 2003).

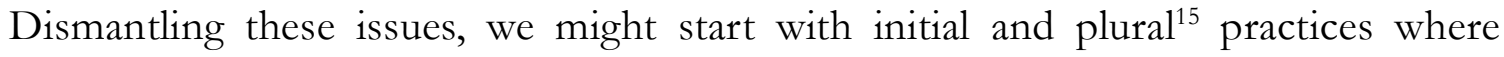
language is a means for students and teachers to locate their understandings about the world; a pedagogical practice oriented more towards the recognition of diversity and aspects influencing students' lives and relationships, as we all feel, think and act differently, a pedagogical pluralism that empowers teachers to trust in what we are-know-do and make visible their experiences. I call this 'critical academic maturity' that is co-constructed and re-constructed through the years of experience and of the dialogues ${ }^{16}$ on those experiences that shed light on new understandings. There is not only one way, but multiple ways. This is what CP advocates, situated encounters with students, colleagues, and friends that make us think about ways others ${ }^{17}$ to deconstruct the areas and homogenizing practices of ELT most of the time.

The legacy of Paulo Freire is revealed in his testimonies, in his personal and pedagogical projects, in his passion to develop a consciousness of freedom, to read the word and the world as inherent to the struggle for justice and democracy. Not only did he impregnate the world with his visionary contributions in his critical pedagogy practice, but he also positioned himself as a social agent that develops a tremendous alternative in Latin American contexts. It was in those incredible dialogues that he defended change

I use this term to pertain to one's own pedagogies as different from the universal ones.

16 Dialogues then become an essential component in the process of transforming our views and actions on a daily basis.

17 The decolonial turn as an epistemological south stance has precisely advocated for ways 'other' of being, knowing and doing, as the critical thoughts that seek to transform the conditions in which Eurocentrism and the coloniality in the world system undermine human beings (coloniality of being), marginalize and invisibilize the plurality of knowledges (coloniality of knowledge) and hierarchize human groups and places in a global power pattern for their exploitation for the sake of the expanded accumulation of capital (coloniality of power). Restrepo \& Rojas (2010). Likewise, Kumashiro (2000) explains that “the term 'other' refers to those groups that are traditionally marginalized in society." (p. 26) 
through self-reflection. He invited us to reflect upon banking education, and from there, he questioned our understanding of teaching and learning acts, because as educators we need to be sensitive, ethical, and respectful with our students' dreams and fears, for them to be able to break their silence and assume a more co-responsible role in this pedagogical process. He clearly stated that there are no recipes, as the path or paths are uncertain. These paths are leading to praxis, to some alternative pedagogical practices in different latitudes.

$\mathrm{CP}$ has enabled me to confront the mainstream Western practices that perpetuate models which look at teachers and students as objects and not as subjects, who need to assume more leading roles, entering into contradictions, deciphering what is happening in our school contexts.

Dialogues and simple actions with my student-teachers, for example, in different classes have caused me to reflect and change the forms in which I have been constructing a sense of an educator. As mentioned above, every day I become more responsive to what is happening in our Colombian contexts, more concerned about the formation processes students go through in initial language teacher education and master's programs. It has been through dialogue that I have been closer to my student-teachers, getting to know more about them, the way they think and act towards teaching and learning, as well as life and schooling. Their experiences and perspectives have become potential tools to engage in a critical recognition of who we are, what we do, what we envision, moving towards a more authentic representation of our lives in our educational contexts. I have learned not to control everything, not to have everything ready, not to have the perfect answer at the perfect time, but rather to give my students the co-responsibility to co-construct our forms of teaching that would definitely transcend to the younger students we have at schools, lovely kids that more important than just learning English or other subjects, need to be listened, loved, and valued. Giving ourselves the path to situate our teaching and to be conscious of the fact that what we name, plan and do as alternative practices, are challenging but amazing in that process of keeping distance from the only-method vision in language teaching. Our common goal has been to believe in ourselves and to make sense of more human pedagogical and research proposals in which language is a means to continue knowing about ourselves and our communities. I think that pedagogical and research practices and encounters, at a personal and professional level, have given meaning to the educator I am becoming, to my doings and what will continue nourishing this meaning in the relationships I am constructing...

Alternative CP practices in our contexts are concerned with offering teachers and students new possibilities to critically understand teaching and learning. They deal with proposing options for students to expand our capacities to question assumptions about what teaching practices are and intervening in our classroom settings where different visions of the world are shared (Samacá, 2012), and where the understandings of their worlds enable both parties to confront our knowledges, our diverse ways of learning how to learn, and our ways of coping with struggles, engagement, and hope. 
Some of these alternative practices have taken different forms; the ones I am addressing here have a special and personal value for the teachings of these teachers and researchers who have considered transcending the instructional dimension of teaching relevant by listening to their students' voices and using the language as a means to recognize themselves and the others. For example, Umbarilla (2010), reported how she engaged students in CP practices that promoted social reflection and cultural recognition in the multicultural scenario of the classroom in order to construct the sense of the other. Gutiérrez (2015) shared her interest in understanding the beliefs, attitudes and reflections of EFL pre-service teachers when exploring critical literacy theories to prepare and implement critical lessons.

Along the same line, Calderón (2017) intended to unveil how tenth graders' life histories gave them the opportunity to understand their difficult life conditions (family, socioeconomic, and academic aspects), to reflect on them and tackle personal problems from a different viewpoint, taking action towards it. This was an insightful study that impacted both the students, the researcher and her mentor, and gave value to what being an 'educator' entails. Peñaloza (2017) revealed how eleventh graders, despite their social and personal issues, (re)constructed their social identity through life stories. Ortega (2009) was intrigued with practices and challenges of CP in the Colombian contexts, from the speeches, projects and scenarios of popular education. López (2016) conducted a study on CP that coped with one of the Freirean tenets of CP: education is a masterpiece, from a phenomenological perspective looking at emotions, love, imagination, and affiliation, as a contribution in the configuration of subjectivities. The ethical view that Ramírez (2008) has given to CP is one that visualizes the epistemological foundation of critical pedagogy and curriculum, and their influence on didactics. These pedagogical and research practices have started to give real meaning to CP in Colombia.

My forms of being, doing, and knowing have started with a deep responsibility to my students, my university, and my program; have underlined a self-reflexivity that takes place in my everyday encounters and actions, and the relationships I construct around the educational contexts $I$ am in contact with.... Forms that help my student-teachers and me not only conceive methodologies to tap into the realities to inquiry, but also to contest and redefine educational practices located in different social, cultural, and economic domains; all this certainly deconstructs the meanings of teaching processes. Thus, we, might continue exploring pedagogies that create spaces for mutual recognition, multiple perspectives towards students' and teachers' conscious growth.

\section{In the Path towards Conscientização ... Some Concluding Thoughts}

As I have mentioned throughout this paper, I am continually redefining myself and the contexts $^{18}$ that I experience on a daily basis, while being engaged with CP. To those who

Contexts are our schools, our classrooms, our teacher education programs, our communities in and from which we are naming ourselves and toward which we should not be passive anymore. 
think that critical pedagogy is a utopia, I would say it is not. Nowadays, we can see initial, attentive, shy discourses and practices that I expect to irradiate more from the periphery to enlighten and value local and plural pedagogies that should resound over those mainstream Western theories, considering the reality of Colombian contexts.

$\mathrm{CP}$ is happening and taking several forms; one of these forms is self-reflexivity and selfrecognition, looking at myself and inviting my students to look at themselves to reconsider previous assumptions associated with ELT. Their real classrooms and school contexts might also contribute to question conventional understandings of theory versus practice, as well as our roles and positionings in education that cannot be legitimized through the reproduction of only Western theories. This realization entails a more complex interaction and dialogues around teachers and students in the diversity of our local contexts. Colombian initial language teacher education programs can contribute to develop a deeper and more situated understandings of second language pedagogy with critical lenses that oppose reinforcing the status quo. These are steps in a larger life and educational project. They will add continuant self/selves-reflexivity and meaning to the decisions that we, teachers, are making and as to how they impact our own teaching, ourselves, and our students' lives and learnings.

My experience through critical pedagogy illustrates somehow significant challenges in self-reflexivity because CP challenges habitual forms of thinking about the relationships with the world. Hopefully, it will have an impact on my future teaching and research agendas in collaborative learning spaces, as it has contributed to my being more respectful, and more self-concious of others' discourses and practices.

\section{References}

Crandall, J. (2000). Language teacher education. Annual Review of Applied Linguistics, 20, 34-55.

Calderón, T. (2017). Critical literacy practices as a self-liberating process (Unpublished master's dissertation). Universidad Distrital Francisco José de Caldas, Bogotá, Colombia.

Freire, P. (1985). The politics of education: Culture, power, and liberation. Connecticut: Bergin \& Garvey.

Freire, P. (1996). 'An incredible conversation'. Interview with Paulo Freire at the World Conference on Literacy organized by the International Literacy Institute in Philadelphia, USA. Available at: http://www.freire.org/paulo-freire

Freire, P. (2005). The pedagogy of the oppressed. New York: Continuum International Publishing Group.

Giroux, H. (2007). Democracy, education and the politics of critical pedagogy. In P. McLaren \& J. Kincheloe (Eds), Critical pedagogy: Where are we now? (pp.1-5). New York: Peter Lang. 
Gutiérrez, C. (2015). Beliefs, attitudes, and reflections of EFL pre-service teachers when exploring critical literacy theories to prepare and implement critical lessons. Colombian Applied Linguistics Journal, 17(2), 55-71.

Kumaravadivelu, B. (2003). Beyond methods: Macrostrategies for Language Teaching. New Haven: Yale University Press.

Kumashiro, K. (2000). Towards a theory of anti-oppressive education. Review of Educational research, 70(1), 25-53.

Lippi-Green, R. (1997). The educational system: Fixing the message in stone. UK: Psychology Press.

López, J. (2016). Pedagogía crítica: la educación es una obra de arte" una contribución a la formación de subjetividades (Unpublished master's dissertation). Universidad Distrital Francisco José de Caldas, Bogotá, Colombia.

McLaren, P. (2003). Critical pedagogy. In D. Gabbard (Ed.), Knowledge and power in the global economy: Politics and the rhetoric of school reform (pp. 345-352). New Jersey: Lawrence Erlbaum Associates.

Magrini, J. M. (2014). Social efficiency and instrumentalism in education: Critical essays in ontology, phenomenology, and philosophical hermeneutics. New York: Routledge.

Mayo, P. (2015). Hegemony and education under neoliberalism. Insights from Gramsci. New York: Routledge.

Monchinski, T. (2008). Critical pedagogy and the everyday classroom. New York: Springer.

Ortega, P. (2009). La Pedagogía Crítica: Reflexiones en torno a sus prácticas y sus desafíos. Pedagogia y Saberes, 31, 26-34.

Pennycook, A. (2001). Critical applied linguistics: A critical introduction. New Jersey: Lawrence Erlbaum Associates.

Pennycook, A. (2007). ELT and colonialism. In J. Cummins \& C. Davidson (Eds), International handbook of English language teaching (pp.13-24). New York: Springer.

Peñaloza, J. (2017). Eleventh graders' life stories: (Re)-constructing social identity through writing-related tasks (Unpublished master's dissertation). Universidad Pedagógica y Tecnológica de Colombia, Tunja.

Phillipson, R. (2003). Linguistic imperialism. Oxford: Oxford University Press.

Ramírez, R. (2008). La pedagogía crítica. Una manera ética de generar procesos educativos. Folios, 28, 108-119.

Restrepo, E., \& Rojas, A. (2010). Inflexión decolonial: fuentes, conceptos y cuestionamientos. Popayán: Editorial Universidad del Cauca.

Samacá, Y. (2012). On rethinking our classrooms: A critical pedagogy view. HOW Journal, 19, 194-208.

Samacá, Y., \& Bonilla, S. X. (Forthcoming). Critical dialogues among ELT student-teachers in a virtual learning environment.

Shaw, V. (2001). Self-dialogue as a fundamental process of expression. Social Thought \& Research, 24, 271-312. 
Shor, I. (1993). Education is politics. Paulo Freire's critical pedagogy. In P. McLaren \& P. Leonard, Paulo Freire. A critical encounter (pp.25-35). New York: Routledge.

Shor, I., \& Freire, P. (1987). A pedagogy for liberation. Dialogues on transforming education. Westport, CT: Bergin \& Garvey Publishers.

Umbarilla, S. (2010). Building students' voices through critical pedagogy: Braiding paths towards the other. Colombian Applied Linguistics Journal, 12, 55-71. 